\title{
OPERATORS MANAGING CALLERS' SENSE OF URGENCY IN CALLS TO THE MEDICAL EMERGENCY NUMBER
}

\author{
Isabella Paoletti
}

\begin{abstract}
Communication in emergency calls is often agitated and callers almost always speak with a sense of urgency. Call operators often have to struggle in order to get the callers' cooperation. The questioning sequence is often perceived by callers as inappropriate and a way of delaying assistance, frequently producing annoyance and anger in the caller. Interrupted calls are not uncommon in communications with the call centre, nor are cursing, rudeness and face attacks. The focus of previous studies on emotional work in emergency calls has mainly been devoted to communication problems and the consequences these had on the provision of assistance. This paper aims to focus specifically on how operators manage callers' anxiety and sense of urgency and the emotions tied to this, such as anger. Transcripts of actual emergency calls are examined through a detailed discourse analysis in order to show operators' interactional work in maintaining emotional contact with callers. The ability of the operators to control their own emotions and manage those of the caller is an important professional skills in this job. Describing how emotional contact with callers is maintained in actual calls can be useful for training and in-service courses.
\end{abstract}

Keywords: Emergency calls; Emotional work; Ethnomethodology; Discourse analysis.

\section{Introduction}

Walking into an emergency call centre, you can often feel the adrenaline pumping. Communication in emergency calls is often agitated as callers are often perturbed and they practically always speak with a sense of urgency. In addition, call operators frequently answer while at the same time hearing the beeping of other incoming calls which are potentially new emergencies, possibly more serious than the one they are dealing with. Call operators certainly have to work while managing their emotions (Tracy \& Tracy 1998a). For example, the address of a person who is having or had had a heart attack has not been provided; in this case every minute is literally of vital importance. Often operators have to make decisions in a few seconds based on very scarce and vague information that can have consequences for the person's life. They describe having to take instant decisions on the basis of insufficient information as one of the most difficult aspects of their job (Paoletti 2009). Call operators also have to find a way to calm down anxious, frightened, shocked 
callers in order to obtain the necessary information and dispatch the ambulance or instruct the caller in how to administer first aid.

In the relevant literature, emotional work is recognized as being an important aspect of emergency personnel work (Tracy \& Tracy 1998a; Whalen \& Zimmerman 1998). Tracy \& Tracy (1998a) describe and give a good sense of what they term "the emotional landscape" of an emergency centre and point out: "Call-taking at 911 is an inherently emotional job that requires call-takers to manage others' feelings as they handle their own" (Tracy \& Tracy 1998a: 396). Tracy and Tracy (1998a) describe a series of specific strategies used by operators in what they term: "double-facet emotional management". (Tracy \& Tracy 1998a: 407). They mainly describe call takers strategies in releasing and controlling their own emotions. Tracy and Tracy underline the importance of a working environment for call takers that allows practices such as evaluative talk off the phone, joking and sharing experiences, in order to release stress, anger, anxiety and so on. In relation to controlling caller's emotion they describe giving advice as an effecting strategy in controlling the stress of caller, (Tracy \& Tracy 1998a). They, though, do not describe such strategies in interactional terms.

Interrupted calls, cursing, rudeness, hysteria, and face attacks are well documented phenomena (Tracy 1997; Tracy \& Tracy 1998a, 1998b; Whalen \& Zimmerman 1998; Whalen et al. 1988). Whalen and Zimmerman (1998) focus on the case of 'hysteria', showing how it is institutionally constructed; in fact, operators describe callers as 'hysterical', not as much in relation to their emotional state, but when they find it difficult to obtain crucial information to organise the rescue activity (Whalen \& Zimmerman 1998: 156). The attention of previous studies on emotion in emergency calls has mainly been devoted to the communication problems generated by the emotional state of callers and the consequences these had for the provision of assistance (Imbens-Bailey \& McCabe 2000; Whalen et al. 1988; Whalen \& Zimmerman 1998). Whalen et al. (1988) describe a communication breakdown with fatal consequences, highlighting the conflict generated through a different ordering of priorities: Operator questioning in order to decide what to do according to the institution's regulations, caller requesting help in a tragic and urgent situation. Studies are lacking that show, in interactional term, the importance of managing emotions in emergency calls, in dramatic instances such as the one described by Whalen et al. (1988) or in the ordinary work of call takers in medical emergency call centres.

Since Hochschild's (1979) pioneering studies on flight attendants, emotional work has been described in various institutional settings (Arminen, \& Halonen 2007; Forsberg 1999; Fineman 2000; Heath 1989; Hepburn and Potter 2007; Hochschild 1979; Kidwell 2006; Toerien \& Kitzinger 2007; Nikander 2007; Ruusuvuori 2007; Suchman et al. 1997; Voutilainen et al. 2010). In their work on children's help lines, Hepburn and Potter (2007: 113) notice an intrinsic tension between emotional work, in particular expressing empathy, and the institutional task at hand: 'The caller may need to be soothed, to be kept on the line, and to feel that they are speaking in a supportive environment. It can be particularly difficult to generate this supportive environment when a key practical task is to elicit evidence for the referral; such questioning almost inevitably sounds sceptical.'

In emergency calls a similar tension is produced between the operator's need for precise information in order to organize the rescue activities efficiently and the caller's sense of urgency and their anxiety to obtain help quickly and promptly. 
There is a growing interest in emotions in a variety of disciplines (Denzin 1984; Firth \& Kitzinger 1998; Reisenzein \& Döring 2009; Turner 2009; White 1990; Wierzbicka 2009), and in particular in language studies (Bamberg 1997; Caffi \& Janney 1994; Edwards 2005; Harré 1988, 2009; Wilce 2009; Wilkinson and Kitzinger 2006). Discursive Psychology (Edwards 2001, 2006, 2007; Potter \& Edwards 2003; Potter 2005) is the field that has developed a particular interest in looking at how emotions are treated conversationally: "how people describe and invoke emotions in everyday talk and text" (Edwards 1999: 271). These studies show how evoking emotions can be used conversationally on a specific occasion to carry out a variety of tasks, and how this is closely related to accountability.

There is a distinction between evoking emotion and expressing or displaying emotions, as Harré (2009) very clearly points out: "In most cases it seems to me that when one is saying "I'm angry with you [about that]" rather than shouting, turning red in the face, and waving one's fists about, one isn't really expressing anger". Attempts to study emotions empirically, as a relevant interactional feature, are on the whole very recent (Pepin 2008). Hepburn and Potter (2007: 90) point out that "Human emotion has overwhelmingly been studied from an individual psychological perspective, and only a small number of studies have started to view emotion as something that appears in, and is perhaps built for, interaction". Goodwin and Goodwin (2000) have looked at emotion within the context of situated activities with, in fact, little or no reference to emotional terms, but emotion display is analysed mainly by embedding it within a sequence of actions, and by looking at various aspects of interaction, including gestures, syntactic choices, intonation, sequential position, timing and pitch differences, among others. Videorecorded material appears particularly helpful in studying emotion.

A relevant problem in relation to describing formally emotional features in an exchange is certainly the difficulty of transcribing emotional overtones, that is, voice quality commonsensically perceivable as having an emotional connotation: Caring, angry and so on. In this respect the studies on laughter (Jefferson 1984, 1985; Jefferson, Sacks, Schegloff 1987) and those on crying (Hepburn 2004; Hepburn and Potter 2007) have greatly contributed to capturing non-verbal elements in the transcripts that are interactionally relevant. Moreover, the studies on emphatic speech style and prosody (Freese \& Maynard 1998; Schegloff 1998; Selting 1992, 1994) have highlighted voice quality aspects such as density of accentuated syllables, rhythmic organization, pitch and loudness, in particular conversational and sequential environments.

Interlocutors show not only an understanding of the meaning of the verbal content of the previous turn, but also its emotional connotation. Interlocutors often orient to the emotional aspect of previous turns. As participants display their understanding of action and discourse turn by turn, in the same way, they appear to show their emotional understanding, methodically and powerfully, turn by turn, as a serious interactional matter. In an interactional exchange the display of emotions- anger or caring, for example - is often commonsensically easy to perceive as are the reactions it elicits. But to show interlocutors' emotional understanding of the previous turn is not straightforward, since emotions are often non-verbally conveyed. Emotions are displayed through a variety of interactional features, quite subtle and substantially interconnected: Sequential features and turn shape, forms of address, choice of words, intonation, pace, pitch, loudness and silence. It is not 
just one aspect but a set of interwoven features that provide what is perceived commonsensically as the emotional connotation of a turn.

The concepts of emotional contact and emotional alignment can be a point of departure in order to make these emotional features of the talk systematically observable. By emotional contact I mean the operator's orientation towards the emotional content of the caller's turn. I argue that the operator's ability to perceive the emotional connotation of the caller's turn and respond to it is an important professional skill. Operators use specific strategies to establish emotional contact, and to maintain and re-establish it: Modifying the speed of speech delivery, changing form of address, asking callers for their telephone number when the interaction gets tense, giving instruction, reassuring callers, informing that the ambulance is on its way; etc. The result of this orientation towards the emotional content of the turn is "emotional alignment", that is, an observable symmetry in some aspects of the talk. Alignment in pace, that is, symmetry in rhythm of speech delivery is one of the most evident aspect in these calls, that results in emotional alignment. For example, if the caller is expressing urgency, the operator acts as if an urgent matter is at stake, maintaining a fast rhythm of speech delivery. Cooperation is achieved. The operator's lack of orientation towards the caller's expression of urgency arouses the caller's anger. The result is emotional disalignment and, in some cases, the complete breakdown of communication.

This study aims to show how operators manage callers' anxiety and sense of urgency, by comparing four calls in which different degrees of callers' expression of anger are noticeable. The schema below represents the four calls in relation to anger arousal: From the expression of rage and a complete breakdown in communication, in the first call; to a total lack of anger and the achievement of a sense of full cooperation among interlocutors, in the fourth call.

$\left.\right|_{\text {Explosion of rage }} ^{1^{\text {st }} \text { call }} \quad 2^{\text {nd }}$ call $\quad$ angry protest mild annoyance $\quad 4^{\text {th }}$ lack of anger

As it will be shown, the main difference between the first and the last call is precisely the alignment among interlocutors in relation to pace.

Callers' expression of urgency is a very frequent phenomenon in this type of call, (Paoletti 2009, 2012). The prompt delivery of help in an emergency is an accountable matter. Operators are not only morally accountable, but legally accountable for the fast and effective provision of assistance. Delay in the delivery of help often leads to a rise in the caller's anger. Interactions are morally regulated (Baker 1997a, 1997b; Bergman 1998; Garfinkel 1967; Heritage \& Lindström 1998; Jayyussi, 1984, 1991; Maynard 1998), as Garfinkel (1967: 35) points out:

"A society's members encounter and know the moral order as perceivedly normal courses of action-familiar scenes of everyday affairs, the world of daily life known in common with others and with others taken for granted. They refer to this world as "the natural facts of life" 
which, for members, are through and through moral facts of life. For members not only are matters so about familiar scenes, but they are so because it is morally right or wrong that they are so."

In fact, in the same way that social actions are inescapably moral, they appear emotionally loaded and the two aspects are often related. That is, the emotional content appears related to the duties inherent to the very organization of talk, for example, the duty of answering questions; or the emotional content is related to the duties inherent to the business at hand, in this case, the duty of responding to the request for help. In other words, a call for help implies the prompt delivery of help. The lack of provision of help or delayed provision of help is morally sanctioned and it can led to a rise in the caller's anger. Summarising schematically, this analysis will explore the following aspects of the interactions:

Actions:

Moral accountability:

Emotional arousal:

Communication outcome: request for help delay in the provision of help

moral implications

anger

from breakdown in communication to full cooperation

The analysis shows that the operator's orientation towards the emotional content of the caller's turn can make a substantial difference to the communication outcomes of the interaction.

\subsection{The study}

The data analysed in this article is part of a wider corpus collected for a research project on language technology, which was started at the Communication Science Department of the University of Bologna, Italy (Paoletti 2006, 2009, 2012). Data was collected in two medical emergency call centres - one in a town in northern Italy and the other in a town in central Italy. It comprises tape recordings of calls from and to the call centre (emergency calls but also calls to and from ambulance drivers, hospitals, etc.), ethnographic observations in the call centres and interviews (with call operators, ambulance drivers, doctors etc.). The transcripts analysed in this paper are all taken from calls collected for the study in central Italy. Names, telephone numbers, street and location names have been changed in order to preserve anonymity.

The data is examined through a detailed discourse analysis (Wetherell et al. 2001), informed by Conversation Analysis (Sacks 1992), within an ethnomethodological theoretical framework (Garfinkel 1967) in order to highlight the call operators' level of ability in managing callers' emotions and maintaining emotional alignment with the callers. In the first transcript we have the caller's violent expression of anger and communication 
breakdown. In the other transcripts, the call operators succeed, to varying degrees, in obtaining the callers' cooperation.

\section{The analysis}

\subsection{Explosion of rage}

Previous studies of emergency calls describe the specific interactional organisation of emergency calls (Wakin \& Zimmerman 1999; Whalen \& Zimmerman 1987; Zimmerman 1984, 1992a, 1992b). For example, Whalen \& Zimmerman (1987) point out that: 'Recognitionals, greetings, and "howareyous" are ... routinely absent in emergency and other types of service calls' (p. 177). A typical five step structure characterizes emergency calls and includes: 1) identification; 2) reason for the call; 3) interrogative series; 4) the response to the request for help; and 5) closing; (Whalen \& Zimmerman 1987). The interrogative series is often resisted by callers. In the interviews, call operators often complained about the caller's unwillingness to provide the relevant information needed to organize the rescue activities (Paoletti 2012: 192). Callers get irritated by the operator's questioning as they perceive it as a way of delaying assistance (Tracy 1997; Whalen et al. 1988). An operator in one interview, for example, described her fear that the caller might hang up; by stating: "the fear of losing the person who is talking to you, this is the fear, you can just feel him slipping away."

In the next transcript the resistance to providing any information whatsoever is remarkable. It contains a violent face attack (Goffman 1967), insults and a threat. The interactional features that trigger the caller's angry response will be highlighted in the course of the analysis. The caller is asking for a doctor. He has been re-directed to 118 after calling a hospital. A caller's re-direction from different health services to 118 is quite a commonplace occurrence in my data.

Extract 1: (Central Italy-C8: 77-80) ${ }^{1}$

\begin{tabular}{|c|c|c|c|}
\hline 1 & $\mathrm{O}$ & $118 ?$ & $118 ?$ \\
\hline 2 & $\mathrm{C}$ & eh good morning who are you? Excuse me & eh buongiorno voi chi siete? Scusate \\
\hline 3 & $\mathrm{O}$ & 118 the ambulance service & 118 servizio di ambulanze \\
\hline $\begin{array}{l}4 \\
5 \\
6 \\
7 \\
8\end{array}$ & $\mathrm{C}$ & $\begin{array}{l}>\text { (but) I need a doctor (instead) the hospital } \\
\text { told me to call (118) I need a doctor they } \\
\text { have put me through to the ambulance } \\
\text { service }<\text { I must (speak) to a doctor it's } \\
\text { urgent! }\end{array}$ & $\begin{array}{l}>\text { (ma a me) mi serve un medico (invece) } \\
\text { l'ospedale m'ha detto chiami il (118) mi } \\
\text { serve un medico mi passano l'ambulanza } \\
\text { io devo (parlà) con un medico è urgente! }\end{array}$ \\
\hline $\begin{array}{l}9 \\
10\end{array}$ & $\mathrm{O}$ & $\begin{array}{l}\text { you want to speak to a doctor? } \\
\text { [for what reason }\end{array}$ & $\begin{array}{lllll}\text { vuole parlare con } & \text { un } & \text { medico? } \\
\text { per }[\text { che cosa } & & & \\
\end{array}$ \\
\hline 11 & & $>\left[\begin{array}{llll}(\mathrm{eh} & \text { damn }) & \text { IT } & \text { IS }\end{array}\right.$ & $>[($ eh mannaggia $) \dot{E} \quad$ URGENTE \\
\hline
\end{tabular}

${ }^{1}$ Transcript notations are provided at the end of the article; some of the terms the participants use are not terms in standard forms of the Italian language. 
Operators managing callers' sense of urgency

677

\begin{tabular}{|c|c|c|c|}
\hline $\begin{array}{l}12 \\
13\end{array}$ & & $\begin{array}{l}\frac{\{\text { BLASPHEMY }\} \text { IT IS URGENT PASS }}{\text { ME A DOCTOR }<} \\
\text { A }\end{array}$ & $\begin{array}{l}\text { \{PORCODDIO }\} \text { È URGENTE MI PASSI } \\
\text { UN MEDICO }<\end{array}$ \\
\hline 14 & & (1.6) & (1.6) \\
\hline 15 & $\mathrm{O}$ & $<$ be calm first of [all ] $>$ & $<$ stia calmo innanzi[tutto] $>$ \\
\hline 16 & ( & $>[\mathrm{NO}] \quad(\mathrm{CALM}$ & $>[\mathrm{NO}](\mathrm{CALMO}$ \\
\hline 17 & & SHIT THEY ARE PISSING ME OFF ( & DEL CAZZO MI STANNO FA GIRANDO \\
\hline 18 & & PASS ME TO A DOCTOR (0.3) & LE PALLE ( ) MI PASSI UN MEDICO \\
\hline 19 & & OTHERWISE I'LL REPORT YOU $<(0.7)$ & (0.3) SENNÒ LA DENUNCIO $<\quad(0.7)$ \\
\hline 20 & & COME ON & FORZA \\
\hline 21 & $\mathrm{O}$ & otherwise you'll report me $=$ & sennò mi mi denuncia $=$ \\
\hline $\begin{array}{l}22 \\
23\end{array}$ & $\mathrm{C}$ & $\begin{array}{l}=\text { YES I'LL REPORT YOU COME ON } \\
\text { TIME IS PASSING= }\end{array}$ & $\begin{array}{l}\text { =>SÍ LA DENUNCIO FORZA CHE } \\
\text { PASSA TEMPO }<=\end{array}$ \\
\hline 24 & $\mathrm{O}$ & $=$ that's not a problem $=$ & $=$ questo non è un problema $=$ \\
\hline $\begin{array}{l}25 \\
26\end{array}$ & $\mathrm{C}$ & $\begin{array}{l}=(\quad) \text { FUCK OFF } \\
((\text { the caller hangs up }))\end{array}$ & $\begin{array}{l}=(\text { )VAFANCULO VA } \\
((\text { l'utente riaggancia }))\end{array}$ \\
\hline
\end{tabular}

In the opening of the call, there are greetings, eh good morning, generally absent in this type of calls, and an identification question, who are you? Notice that the question is accompanied by an apology, excuse me, that acknowledges the oddness of the conversational move. In fact, callers are generally accountable for knowing who they are calling. Nevertheless we learn in the next turn, in lines 4-8, that the caller had phoned the hospital and was put through to the emergency service; consequently he was not quite sure who was going to answer the phone.

The operator repeats the institutional self-identification, adding a specification, 118 the ambulance service. Generally, at this point in emergency calls, the caller expresses the reason for the call. In this case, we have a request, (I need a doctor), a request embedded in a complaint sequence (Monzoni 2008, 2009a, 2009b; Jefferson 1984; Drew 1998). In fact, an indirect complaint, since it refers to the interlocutor of the initial call to the hospital, $>I$ need a doctor they have put me through to the ambulance service $<$. The caller produced the complaint contrasting his request, I need a doctor, with the description of the unsatisfactory results he managed to obtain in a previous call, they have put me through to the ambulance service. The turn is designed to convey misconduct on the part of the previous interlocutor. Notice that the turn is produced at a faster pace, compared to the rhythm of the speech delivery of the caller's previous turn. Then the caller very explicitly points out the urgency of his request: I must (speak) with a doctor it is urgent! The caller appears to express annoyance and frustration through the complaint since his pressing need to talk to a doctor has not been addressed. The operator repeats the last part of the caller's turn, you want to speak to a doctor. Repetitions of a previous turn or part of it are generally produced as other-initiated repairs (Schegloff et al. 1977: 365). Then she solicits an explanation for the call, [for what reason. In this way she is returning to the institutional interactional organization of emergency calls (Whalen and Zimmerman 1987; Wakin and Zimmerman 1999), that is, she initiates the interrogative series. Institutionally, operators are there to deliver ambulances; moreover, they are responsible for the management of scarce 
resources, deciding which means and personnel should intervene in an event in relation to the seriousness of it; thus they function as a filter.

At this point, the caller literally bursts out in an explosion of anger. He starts yelling and swearing, > [ (eh damn) IT IS URGENT \{BLASPHEMY\} IT IS URGENT PASS ME A $D O C T O R<$. The operator's turn is perceived as a further delay to the caller's pressing request for help and yet another source of annoyance and frustration in relation to his unattended needs. This call represents the caller's second attempt to talk to a doctor. Moreover an emotional misalignment is noticeable among caller and operator. The caller formulated a complaint and explicitly expresses urgency, it is urgent, as well as implicitly, using a fast speech delivery rhythm. The operator ignores the irritation expressed in the complaint by the caller and her answer maintains a slow speech delivery rhythm, both these aspects contribute to produce an effect of disaligment among interactants. The repetition of the caller's request in particular confers a sense of accentuated slowness and, moreover, it results in problematizing the request. It would have been different, for example, if the operator had replied "for what reason", without repeating the question. In this call both operator and caller use the courtesy form of address in Italian (third person singular), which is lost in the English translation. This is the most usual form of address in an institutional encounter.

After the caller's explosion of anger, there is a brief pause, (1.6), but noticeable in this type of context, which is attributable to the operator. Then the operator explicitly addresses the face attack (Goffman 1967), inviting the caller to regain control, <be calm first of [all ]>, in a normal tone of voice and at a slower pace compared to her previous turn. Her conversational move is not successful; in fact, the caller keeps yelling and swearing and adds a threat, >OTHERWISE I'LL REPORT YOU<(0.7) COME ON. The operator again repeats the last part of the caller's turn in a normal tone of voice, otherwise you'll report $m e=$, apparently an other-initiated repair (Schegloff et al. 1977, 365), which is, in fact, a move in what has become an open confrontation. The caller repeats the threat yelling, = >YES I'LL REPORT YOU COME ON TIME IS PASSING $<=$. The operator directly addresses the threat, connoting it as irrelevant, =that's not a problem $=$. The operator's reply could be seen as also addressing the second part of the caller's turn, COME ON TIME IS PASSING. In this way, she would be explicitly disregarding the expression of urgency of the caller. This would be an even more conflicting move, in that she would not just be defending herself from a threat, but she would be attacking the caller by treating the caller's request for prompt intervention as irrelevant. The caller yells and swears again and hangs up.

This type of call is not that unusual in this kind of data. Violent face attacks are well documented phenomena in the relevant literature (Tracy and Tracy 1998a). The operator does not manage to obtain relevant information from the caller in order to provide help. The caller's anger seems triggered mainly by the operator ignoring the sense of urgency expressed, in this case explicitly and implicitly, by the caller, and the irritation expressed through the complaint in relation to the previous, also ineffective, call to the hospital. It is mainly the turn shape, marked by repetitions (other-initiated repair) and the pace (slower) of the operator's turn that show complete misalignment with the caller's complaint and expression of urgency; this is added to the fact that this call is positioned as the caller's second attempt at getting help. The asymmetry in rhythm of speech delivery among 
interlocutors is probably the most noticeable feature of this call. In all the calls examined here, symmetry/asymmetry in the speed of speech delivery is present as a marked feature of emotional alignment/misalignment. In the analysis of the transcripts that follow, the different degrees of success regarding the various attempts of the operators to align themselves with the emotional content of the talk are highlighted.

\subsection{Angry protest}

The transcript below relates to a fight in a disco. This transcript is a relevant example of resistance to the questioning series not only since the caller does not provide the relevant information, but also because he explicitly protests about the operator's questioning.

Extract 2: (Central Italy-C8: 112-115)

\begin{tabular}{|c|c|c|c|}
\hline 1 & $\mathrm{O}$ & 118 & 118 \\
\hline $\begin{array}{l}2 \\
3 \\
4\end{array}$ & $\mathrm{C}$ & $\begin{array}{l}\text { eh please come to the Pavone there is a } \\
\text { ((a loud noise in the background)) (a ) } \\
\text { wounded person }\end{array}$ & $\begin{array}{l}\text { eh per cortesia venite al Pavone che c'è } \\
\text { un: ((un forte rumore di sfondo)) (na ) } \\
\text { ferito }\end{array}$ \\
\hline 5 & $\mathrm{O}$ & where? & dove? \\
\hline 6 & $\mathrm{C}$ & at Pavone the disco in Mileto & al Pavone la dis \\
\hline 7 & & $(0.8)$ & $(0.8)$ \\
\hline $\begin{array}{l}8 \\
9 \\
\end{array}$ & $\mathrm{O}$ & $\begin{array}{l}\text { what happened exactly ((a crowd talking } \\
\text { in the background)) }\end{array}$ & $\begin{array}{l}\text { che succede di preciso ((si sente la folla } \\
\text { parlare nel sottofondo)) }\end{array}$ \\
\hline 10 & & $(1.5)$ & $(1.5)$ \\
\hline 11 & $\mathrm{C}$ & $($ you? $)=$ & (lei?) $=$ \\
\hline $\begin{array}{l}12 \\
13 \\
14\end{array}$ & $\mathrm{O}$ & $\begin{array}{l}=\text { no I haven't understood what has } \\
\text { happened exactly= ((stressing each syllable } \\
\text { of "exactly" }))\end{array}$ & 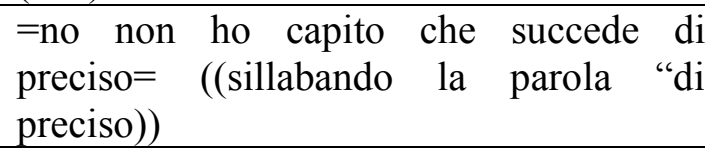 \\
\hline $\begin{array}{l}15 \\
16 \\
17 \\
\end{array}$ & $\mathrm{C}$ & $\begin{array}{l}=\text { well there is there has been a fight there } \\
\text { is a wounded person at the Pavone in } \\
\text { Mileto }\end{array}$ & $\begin{array}{l}=\text { allora c'è c'è stata una rissa c'è un ferito } \\
\text { al Pavone de Mileto }\end{array}$ \\
\hline 18 & & $(0.6)$ & $(0.6)$ \\
\hline 19 & $\mathrm{O}$ & what's wrong with him exactly? & che c'hs \\
\hline $\begin{array}{l}20 \\
21 \\
22 \\
\end{array}$ & $\mathrm{C}$ & $\begin{array}{l}\text { eh he is on the ground and what do I have } \\
\text { to do what can I say (what can I say) just } \\
\text { come come on?! (0.3) eh! }\end{array}$ & $\begin{array}{l}\text { eh: sta a terra che te devo fa che te devo } \\
\text { dì (che ve devo dì ) venite su no?! }(0.3) \\
\text { eh! }\end{array}$ \\
\hline $\begin{array}{l}23 \\
24 \\
\end{array}$ & $\mathrm{O}$ & $\begin{array}{l}\text { could give me your telephone number } \\
\text { please? }\end{array}$ & mi lasci il numero di telefono per favore? \\
\hline 25 & $\mathrm{C}$ & yes $\downarrow$ three four zero & sì:: $\downarrow$ tre \\
\hline 26 & & $(1.3)$ & $(1.3)$ \\
\hline 27 & $\mathrm{O}$ & Yes & Sí \\
\hline 28 & $\mathrm{C}$ & ninety seven zero six nine two & novantasette zero sei nove due \\
\hline 29 & $\mathrm{O}$ & $=$ ok we'll be the[re at once $\downarrow$ & $=$ vabbene arrivia[mo subito $\downarrow$ \\
\hline
\end{tabular}




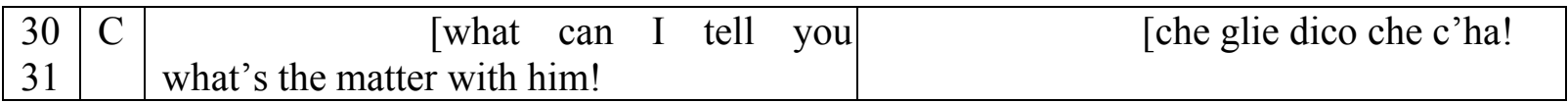

Introducing the reason for the call, please come to the Pavone there is a ...(a) wounded person, the problem of "frame", as Tracy (1997: 316) describes it, is immediately evident: "Citizens ... frequently bring a "customer service" frame to the exchange, whereas emergency call takers assume what I have labelled a "public service" frame'. In other words, callers ask for an ambulance as they would call a taxi, but this is not how the procedure is carried out: Operators need to assess the patient's condition and the overall emergency scene in order to decide which resources and personnel to send. The operator starts the questioning series, attempting to elicit information from the caller about the condition of the person in need of help, in order to send the most appropriate resources to deal with the emergency, but he does not get much cooperation.

In the next turn, line 5, the operator asks for clarification to ascertain the right location, where?, starting the questioning series. The caller repeats the location, line 6. To understand the location is of course an issue of primary importance. There is a short pause attributable to the operator. Then the call operator asks the caller to provide details about the event that caused the emergency, what exactly happened. The small pause after the question and the inaudible turn at line 11 are understood as a request for clarification by the call operator, since this is provided by repeating the question and emphasising the final word, no I haven't understood what has happened exactly=((stressing each syllable of "exactly")). In his quick reply - notice the latching - the caller provides a new item of information about the casualty: A context for it, which is a fight, a commonsensically acceptable context in which somebody can be wounded: =well there is there has been a fight. Then the caller repeats exactly the same initial formulation, there is a wounded person at the Pavone in Mileto. What precisely does he want to do? The caller repeats the most relevant information there is to know, probably hinting at the fact that this is all you need to know in order to come to the aid of the wounded person. Again we have a small pause noticeable in this type of context, attributable to the operator. Then he formulates a new question about the condition of the wounded person, what's wrong with him exactly? The pauses, even if very brief, are a noticeable feature of this call. In emergency calls, the exchange is often excited and latchings and overlappings are more frequent than pauses. Speed of speech delivery is average in this call, but the pauses, mainly attributable to the operator, confer a sense of slowness to the call.

At this point, the protest comes. The caller is still attempting to cooperate in providing a new item of description, eh he is on the ground, but then he gives vent to his annoyance and impatience, and what do I have to do what can I say (what can I say). Then the caller urges intervention, just come come on! (0.3) eh! As was pointed out above, interactions are morally regulated (Garfinkel 1967; Jayyusi 1984, 1991). The operator's request for information is resisted. The caller is reproaching the call operator, connoting his behaviour as improper and uncooperative. He does so through formulating a rhetorical question, what do I have to do what can I say. With this question, he expresses his inability to provide information about the wounded person's condition. The caller is resisting an identity attribution as a person able to comment on a medical condition. He protests 
because this is not his job, but his interlocutor's job. Then the caller explicitly signals that the right thing to do right now would be just to come immediately with the ambulance and rescue the wounded person, just come. Notice the exclamations: venite su no?! (0.3) eh!/come on!?(0.3) eh!; both these expressions appeal to common sense, as if to say: "don't you think that coming here in a hurry is the right thing to do right now?" In particular "eh!" reinforce the reproaching connotation of the turn at talk.

The call operator ignores the face attack (Goffman 1967) and changes subject, asking for the second most important information in an emergency call - a contact number, could you give me your telephone number please? $\downarrow$. The caller provides the number. Cooperation is re-established. Asking for the telephone number appears as a strategy which inserts an element of change and it is a question easy to be answered. In an emotionally tense exchange, as in this case, it appears as a strategy to re-establishes emotional contact. The caller's reply is prefaced by, yes $\downarrow$, with falling intonation. The elongation and the falling intonation seem to mark the reply as being an unwilling concession. This is an important piece of information that allows the operators to call back and possibly obtain more information after the ambulance has been dispatched, but also a means of regaining emotional contact. Then the operator replies quickly: Notice the latching, and announces the acceptance of the request for help, $=o k$ we'll be there at once $\downarrow$, with falling intonation. The falling intonation characterizes the turn as pre-closing. A turn granting the response to a request for help is generally followed by a brief closing sequence (Whalen \& Zimmernan 1987). In this case, though, the caller repeats his protest, what can I tell you what's the matter with him. Closing turns are absent.

In this passage, it is worth noticing the use of address forms. In an institutional exchange formal address (third person singular) is normally used in Italian, but we have a switch to informal address in this call. In fact it starts with caller using second person plural (venite) at line 2, a typical address form in an institutional interaction ${ }^{2}$. Then the caller uses informal address (che te devo fa, second person singular). In his next turn the operator reciprocates using informal address, the second person singular of the verb (mi lasci) ${ }^{3}$; the difference is lost in the English translation. In the last turn, line30-31, the caller goes back to formal address (che glie dico). Also, in this way, he seems to misalign himself with the operator.

There is not much sense of cooperativeness established in this call, although there are various operator attempts to regain contact and show alignment with the caller. The caller is underlining the inadequacy of the operator's request to provide information regarding the medical condition of the wounded person. The caller's remark is a protest in relation to identity attribution. With his remark, the caller is saying: "I am not a doctor, I cannot say what's wrong with him. I am an ordinary person who has done his duty calling for help". The caller is angry because he sees the questioning as improper and a useless

${ }^{2}$ This address form (second person plural) signals the institutional character of the occasion, see Drew \& Heritage, (1990: 30) for the use of "we" rather than I for personal reference, in institutional interaction.

3 "Mi lasci" is also a form of formal address (the imperative form, 3rd person singular), but not in this case since the rising intonation clearly connotes the sentence as a question. 
delay in relation to the provision of help. The operator is annoyed because the caller is not cooperating effectively. The asymmetry in pace is not evident in this call, although there are some pauses, mainly attributable to the operator, which are noticeable in this type of context. In the next call there is a similar kind of communication problem, but with a different interactional outcome: More effective cooperation is established between the interlocutors.

\subsection{Expression of annoyance}

The next transcript refers to a call about a car accident. As in the previous one, the caller shows some resistance to the questioning series, but to a lesser degree, and cooperation is achieved.

Extract 3: (Central Italy-C8: 174-192)

\begin{tabular}{|c|c|c|c|}
\hline 1 & $\mathrm{O}$ & $>118$ emergency service yes? $<$ & $>118$ pronto soccorso dica? $<$ \\
\hline $\begin{array}{l}2 \\
3 \\
4 \\
5 \\
6\end{array}$ & $\mathrm{C}$ & $\begin{array}{l}\text { listen (eh ) this is the Faltaro mountain } \\
\text { pass in the municipality of Marcia there } \\
\text { has been an accident } \\
\text { [(I wo- I wanted to inform ) an injured } \\
\text { lady < }\end{array}$ & $\begin{array}{l}\text { >senti (eh ) è la forca di Faltaro comune di } \\
\text { Marcia c'è stato un incidente } \\
\text { [(vole- volevo avvertí ) na signora ferita< }\end{array}$ \\
\hline 7 & $\mathrm{O}$ & [ yes listen are the persons conscious? & [ sì ascolta sono coscienti le persone? \\
\hline 8 & $\mathrm{C}$ & yes: but for today eh $=$ & sì: ma é per oggi eh= \\
\hline 9 & $\mathrm{O}$ & $=$ listen where is the mountain pass of? & $=$ ascolta dove forca di? \\
\hline 10 & $\mathrm{C}$ & $\begin{array}{l}\text { Faltaro mountain pass in the municipality } \\
\text { of Marcia }\end{array}$ & forca di Faltaro comune di Marcia \\
\hline 11 & $\mathrm{O}$ & where is this place located? & dove si trova questa località? \\
\hline $\begin{array}{l}12 \\
13\end{array}$ & $\mathrm{C}$ & $\begin{array}{l}\text { eh::m between Malarro and (b- ) between } \\
\text { (the and Amsarga) }\end{array}$ & $\begin{array}{l}\text { ( ) eh::m tra Malarro e (t- ) tra:: (il } \\
\text { Amsarga) }\end{array}$ \\
\hline 14 & $\mathrm{O}$ & ( ) street? & ( )via? \\
\hline 15 & $\mathrm{C}$ & Amsarga street & via Amsarga \\
\hline 16 & $\mathrm{O}$ & Amsarga? & Amsarga? \\
\hline $\begin{array}{l}17 \\
18\end{array}$ & $\mathrm{C}$ & $\begin{array}{l}\text { yes but call it (Tessa) and they know } \\
\text { immediately where it is eh= }\end{array}$ & $\begin{array}{l}\text { sì però lo chiamano (Tessa) e lo sanno } \\
\text { subito dove si trova eh= }\end{array}$ \\
\hline $\begin{array}{l}19 \\
20\end{array}$ & $\mathrm{O}$ & $\begin{array}{l}\text { please leave me your local telephone } \\
\text { number? }\end{array}$ & $\begin{array}{l}=\text { mi lascia il numero di telefono locale per } \\
\text { favore? }\end{array}$ \\
\hline 21 & $\mathrm{C}$ & eh six six (.) eigh- so six eight one & eh: sei sei: (.) otto- allora sei otto uno \\
\hline 22 & $\mathrm{O}$ & six eight one & sei otto uno \\
\hline 23 & $\mathrm{C}$ & (.) seven two & (.) sette due \\
\hline 24 & $\mathrm{O}$ & seven two & sette due \\
\hline 25 & $\mathrm{C}$ & (.) fifty two & (.)cinquantadue \\
\hline 26 & $\mathrm{O}$ & (.) fifty two & (.)cinquantadue \\
\hline 27 & $\mathrm{C}$ & three hundred and thirty six & trecentotrentasei \\
\hline
\end{tabular}




\begin{tabular}{|c|c|c|c|}
\hline 28 & $\mathrm{O}$ & three hundred and thirty six $=$ & trecentotrentase $\mathrm{i}=$ \\
\hline 29 & $\mathrm{C}$ & $=$ but make it quick [ ( & $=$ ma na cosa veloce $[($ \\
\hline $\begin{array}{l}30 \\
31\end{array}$ & $\mathrm{O}$ & $\begin{array}{l}\text { [yes lis- listen the } \\
\text { ambulance is leaving }\end{array}$ & 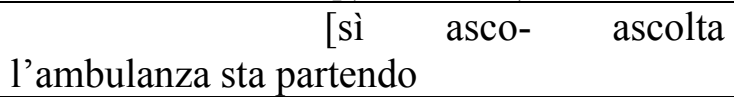 \\
\hline 32 & $\mathrm{C}$ & yes $=$ & sí= \\
\hline 33 & $\mathrm{O}$ & $=$ what's your name please & $=$ lei come si chiama per favore \\
\hline 34 & $\mathrm{C}$ & Fiorenzo Mazzaleno & Fiorenzo Mazzalemo \\
\hline $\begin{array}{l}35 \\
36\end{array}$ & $\mathrm{O}$ & $\begin{array}{l}\text { eh Mister (Mazaleno)(.) } \\
\text { list[en }\end{array}$ & $\begin{array}{l}\text { eh signor (Mazaleno) (.) } \\
\text { 'scol[ti }\end{array}$ \\
\hline 37 & $\mathrm{C}$ & [shall I call the police too? & [devo chiamare anche i carabinieri? \\
\hline 38 & $\mathrm{O}$ & I'll call the police $=$ & li chiamo io i carabinieri $=$ \\
\hline $\begin{array}{l}39 \\
40\end{array}$ & $\mathrm{C}$ & $\begin{array}{l}\text { (you have to call them) because here the } \\
\text { cars are a write-off eh= }\end{array}$ & $\begin{array}{l}=(\text { deve chiamà lei) perché qui le macchine } \\
\text { son distrutte eh= }\end{array}$ \\
\hline $\begin{array}{l}41 \\
42 \\
43 \\
44\end{array}$ & $\mathrm{O}$ & $\begin{array}{l}=\text { yes it's not me who's coming ( it is } \\
\text { ok) listen including the other things um } \\
\text { are the persons conscious are they } \\
\text { bleeding can you see }\end{array}$ & $\begin{array}{l}=\text { sì non è che vengo io ( } \\
\text { ascolti comprese le altre cose m::: le } \\
\text { persone sono coscienti perdono sangue che } \\
\text { lei vede }\end{array}$ \\
\hline 45 & $\mathrm{C}$ & yes they are conscious but it is a thing $\mathrm{so}=$ & sì so coscienti però è una cosa tanto $=$ \\
\hline $\begin{array}{l}46 \\
47 \\
48 \\
\end{array}$ & $\mathrm{O}$ & $\begin{array}{l}\text { =yes but instead of asking questions } \\
\text { answer mine (.) it is } \\
\text { [(quicker) }\end{array}$ & $\begin{array}{l}\text { =sì ma se lei anziché farmi delle domande } \\
\text { risponde alle mie }(.) \text { facciamo } \\
{[\text { (prima) }}\end{array}$ \\
\hline 49 & $\mathrm{C}$ & {$[($ yes yes $[$ ) } & [( sì sì [ ) \\
\hline 50 & $\mathrm{O}$ & [are the persons bleeding? & [perdono sangue le persone? \\
\hline 51 & $\mathrm{C}$ & that lady from her head & quella signora dalla testa \\
\hline 52 & $\mathrm{O}$ & very well $\downarrow$ (.) thank you & benissimo $\downarrow$ (.)la ringrazio \\
\hline 53 & & $(2.0)$ & $(2.0)$ \\
\hline 54 & $\mathrm{C}$ & Goodnight & buonasera \\
\hline 55 & $\mathrm{O}$ & Goodbye & arrivederci \\
\hline
\end{tabular}

The operator starts the call with a fast speed of speech delivery and so does the caller. The caller answers with a location, >listen (eh) this is the Faltaro mountain pass in the municipality of Marcia $<$, and the reason for the call, there has been an accident, signalling the presence of an injured person, $>$ [(I wo- I wanted to inform ) an injured lady<, showing that this is an urgent matter to be attended to. The sense of urgency is communicated not only by the content of the sentence but by the fast pace at which the sentence is produced. The operator starts the questioning series with a question aimed at ascertaining the condition of the persons involved in the accident and, consequently, the level of urgency of the intervention, yes listen are the persons conscious? The caller answers, yes, and adds an ironic remark which is a comment on the need for quick intervention, yes but for today eh $=$. In this way, the caller is making the operator accountable for the prompt delivery of help. The operator does not address this mild face attack (Goffman 1967), but replies quickly - notice the latching - and changes topic, to ascertain the exact location of the accident, =listen where is the mountain pass? This is the most important information there 
is to know. In changing topic and replying quickly, the operator addresses the emotional content of the caller's turn, that is, the expression of urgency.

There are several turns devoted to the issue of localization and the caller suggests a locally used name for the site that can help in finding it, yes but call it (Tessa) and they know immediately where it is eh=. With the choice of words, they know immediately, he seems to frame his turn to express urgency and the need for prompt intervention. The operator changes topic and asks for his telephone number, = please leave me your local telephone number? In this way, he addresses the caller's previous indirect expression of urgency, conveyed through the choice of the term "immediately". As pointed out above, asking for the telephone number is often used to re-establish cooperation. As in the previous call, the request for the telephone number is formulated as giving an instruction.

Some turns are devoted to communicating the number. Then the caller explicitly comments on the need for fast intervention line 29, =but make it quick [( ). The operator overlaps with the caller's turn, granting the response to the request for help, [yes lis- listen the ambulance is leaving, reassuring the caller that the ambulance is on its way. Then he continues to ask questions. Through the reassuring move, the operator can be seen to orient himself towards the emotional content of the caller's previous turn when expressing urgency. In this turn the operator uses informal address (ascolta, the second person singular), as at the beginning in line 7 and line 9, in all the others turns, both operator and caller use formal address. It appears as a move towards establishing emotional contact with the caller. In fact, the operator asks the caller to identify himself $=$ what's your name please. After the identification is provided, the operator addresses the caller by his name, eh (Mister (Mazaleno)(.) list[en ). It seems that the operator is attempting to establish personal contact with the caller. But he is interrupted by a question from the caller, [shall I call the police too?, an unusual instance in this type of call. In fact, it is normally the operator who asks questions. It appears to be a form of resistance in relation to the operator's move. The operator answers, I'll call the police $=$. The caller's next turn is not clearly audible, and then the operator remarks on some institutional feature of the organization of the emergency service, =yes it's not me who's coming ( it is ok). This turn is similar to the previous one, designed to reassure the caller. By stating that he is not going to the site of the accident, the operator is seeking to explain how the emergency service is organized and that they can be talking while the ambulance is leaving.

Then the operator asks another question about the condition of the people involved in the accident, are the persons conscious are they bleeding can you see. This was his initial question. The caller answers but also starts an explanation, yes they are conscious but it is a thing $s o=$. At this point the operator replies and stops the caller in the middle of the sentence. There are no overlaps, just a latching. The operator reproaches the caller, instructing him on the institutionally appropriate way of behaving on such an occasion, =yes but instead of asking questions you answer mine. He also explicitly addresses the main issues raised by the caller, it is [(quicker). The caller aligns himself with the operator's request, [(yes yes [ ). The operator, overlapping with the last part of the caller's turn, refocuses on one of the main aims of the call: That of ascertaining the condition of the patients, [are the persons bleeding? This time the caller provides a relevant answer, that lady from her head. The operator's reply, very well (.) $\downarrow$ thank you, with its falling intonation, signals the pre-closing of the call. After a short pause, a brief closing sequence 
ends the call. In this passage, the operator can be seen instructing the caller on how to behave in this institutional encounter (see Paoletti 2012 for similar "instructing" instances). He manages to obtain an institutionally satisfactory exchange, that is, relevant information about the condition of the individuals involved in the accident, and as such he acknowledges the caller's alignment with his request. In fact, this last sequence resembles the features of classroom interaction (Mehan 1979).

In this call the operator is able to align himself with the sense of urgency expressed by the caller, and to obtain the most relevant information he needs to organize the rescue activity. In both the turns in which the caller expresses the need for prompt intervention, through the ironic remark at line 8 and the explicit comment at line 29, the operator acknowledges the emotional content of the caller's turns, replying quickly and changing topic in the first case (line 9) and then reassuring the caller that the ambulance is on its way (line 30-31). Even the operator's protest (line 46-48), in fact, addresses the caller's concern for prompt intervention. A greater sense of cooperation appears to be established in this call, when compared to the previous ones.

The following call is quite ordinary. It is brief and it runs smoothly. The operator does not manage to get particularly useful information from the caller in relation to the event, but it is noteworthy because of the impression of cohesiveness that it conveys, that is to say, the sense of cooperation that is established between caller and operator. For this reason it appears in various ways to be in contrast with the previous calls.

\subsection{Lack of anger: Maintaining emotional alignment}

The transcript that follows is the first of a series of calls all pertaining to the same event - a car accident with one injured and one fatal casualty. It is just an ordinary call in which the operator is doing her job: Trying to obtain information from the caller in order to organize the rescue activities; however, her ability to maintain emotional contact with the caller is remarkable.

Extract 4: (Central Italy-C8: 16-21)

\begin{tabular}{|c|c|c|c|}
\hline 1 & 0 & $118 ?=$ & centodiciotto? $=$ \\
\hline 2 & $\mathrm{C}$ & $=$ hallo & $=$ pronto \\
\hline 3 & $\mathrm{O}$ & hallo yes & pronto dica \\
\hline $\begin{array}{l}4 \\
5\end{array}$ & $\mathrm{C}$ & $\begin{array}{l}\text { an emergency here a serious accident here } \\
\text { in Scabrini\} street }\left(\left[\begin{array}{ll}{[}\end{array}\right)\right.\end{array}$ & $\begin{array}{l}\text { un' urgenza qui un incidente grave qui a } \\
\text { via Scabrini ( }\left[\begin{array}{l}\text { [ } \\
\text { via }\end{array}\right.\end{array}$ \\
\hline 6 & $\mathrm{O}$ & [yes (] & [allora (] \\
\hline $\begin{array}{l}7 \\
8\end{array}$ & $\mathrm{C}$ & $\begin{array}{l}\text { Scabrini street at the crossroads } \\
\text { [yes] }\end{array}$ & Scabrini \\
\hline $\begin{array}{l}9 \\
10\end{array}$ & $\mathrm{O}$ & $\begin{array}{l}\text { [ ok]ay (Scabrini street ) how many cars } \\
\text { are involved= }\end{array}$ & $\begin{array}{l}\text { [al]lora (via Scabrini ) quante machine } \\
\text { sono coinvolte= }\end{array}$ \\
\hline 11 & $\mathrm{C}$ & $=$ well two cars $=$ & $=$ beh due macchine $=$ \\
\hline 12 & $\mathrm{O}$ & $=$ how many injured persons & $=$ quanti feriti \\
\hline 13 & $\mathrm{C}$ & ) one is certainly in a critical & eh che: ( ) un uno sicuramente grave \\
\hline
\end{tabular}




\begin{tabular}{|c|c|c|c|}
\hline 14 & & condition & \\
\hline $\begin{array}{l}15 \\
16\end{array}$ & $\mathrm{O}$ & $\begin{array}{l}\text { ah two injured persons listen can you see } \\
\text { are they trapped? }\end{array}$ & $\begin{array}{l}\text { ah due feriti senta che lei vede sono } \\
\text { incastrati? }\end{array}$ \\
\hline $\begin{array}{l}17 \\
18\end{array}$ & $\mathrm{C}$ & $\begin{array}{l}\text { hh wel- ( ) eh (.) I because I don't know I } \\
{[(()]}\end{array}$ & $\begin{array}{l}\text { hh allo- ( ) eh (1.1) io perché non so- io } \\
{[(\mathrm{C})]}\end{array}$ \\
\hline $\begin{array}{l}19 \\
20\end{array}$ & $\mathrm{O}$ & $\begin{array}{l}\text { [don]'t worry leave me your telephone } \\
\text { number }\end{array}$ & $\begin{array}{l}\text { [no ]n si preoccupi mi lasci il suo numero } \\
\text { di telefono }\end{array}$ \\
\hline 21 & $\mathrm{C}$ & ) >zero seven four two $<$ & ) >zero sette quattro due $<$ \\
\hline 22 & $\mathrm{O}$ & yes & sì:: \\
\hline 23 & $\mathrm{C}$ & nine zero two eight two & nove zero due otto due \\
\hline 24 & $\mathrm{O}$ & nine zero two? & nove zero due? \\
\hline 25 & $\mathrm{C}$ & eight two & otto due \\
\hline $\begin{array}{l}26 \\
27\end{array}$ & $\mathrm{O}$ & $\begin{array}{l}\text { listen do you (see that) the persons are not } \\
\text { moving? }\end{array}$ & $\begin{array}{l}\text { senta lei (vede che) non si muovono le } \\
\text { persone? }\end{array}$ \\
\hline $\begin{array}{l}28 \\
29 \\
30 \\
31\end{array}$ & $\mathrm{C}$ & $\begin{array}{l}\text { they they have told me to call as I was } \\
\text { here at home (they have) "call } 118 \\
\text { immediately" and I did I didn't go down } \\
\text { my brother went down he is down }\end{array}$ & $\begin{array}{l}\text { mi mi hanno detto di chiamarlo che io } \\
\text { stavo qui a casa (hanno) "chiama subito il } \\
\text { centodiciotto" e i' son io 'n son andato } \\
\text { giù è andato giù mi' fratello che sta giù }\end{array}$ \\
\hline $\begin{array}{l}32 \\
33\end{array}$ & $\mathrm{O}$ & $\begin{array}{l}\text { okay then leave this } \\
\text { numb[er free I'll call back directly }\end{array}$ & $\begin{array}{l}\text { va bene allora lasci libero questo } \\
\text { nu[mero che adesso la richiamo }\end{array}$ \\
\hline 34 & $\mathrm{C}$ & [eh & {$[\mathrm{eh}$} \\
\hline 35 & $\mathrm{O}$ & okay?= & va bene?= \\
\hline 36 & $\mathrm{C}$ & $=$ thank you $=$ & $=$ grazie $=$ \\
\hline $\begin{array}{l}37 \\
38 \\
\end{array}$ & $\mathrm{O}$ & $\begin{array}{l}=\text { and you will give me more information } \\
\text { while I send them there okay?= }\end{array}$ & $\begin{array}{l}=\text { e mi sa dare maggiori notizie intanto gli } \\
\text { mando loro va bene? }=\end{array}$ \\
\hline 39 & $\mathrm{C}$ & $=$ yes thank you than[k you] & $=$ sì grazie gra[zie] \\
\hline 40 & $\mathrm{O}$ & [thank] you & [gra]zie \\
\hline
\end{tabular}

At line 4-5, the caller then produces the reason for the call, an emergency here a serious accident here in \{Scabrini\} street( [ )]. The caller implicitly communicates urgency with the adjective "serious", signalling the need to provide help as soon as possible. The caller directly adds the location of the accident. The place must be familiar to the call operator since she does not ask for any clarification but simply acknowledges the location. Notice the overlaps and the latching that show the fast alternation of turns among the interlocutors.

At this point the questioning series starts. The operator asks questions that have a specific meaning in terms of the organisation of the rescue activities. In the first question, the operator is attempting to picture the scene of the accident, line 9-10. This in particular appears to unpack the seriousness of the accident referred to by the caller, a serious accident. Firstly, the operator asks about the magnitude of the event, how many cars are involved $=$, and immediately afterwards about the condition of the people involved =how many injured persons. Since the caller's answer, $=$ well two cars $=$, allows the operator to categorize the accident as ordinary, she then starts to explores the other issues implied in a serious accident: Casualties. The Italian expression "beh" (well) generally expresses 
hesitation. "Well" (beh) seems to retrospectively refer to the seriousness of the accident that the caller has previously mentioned (lines 4 and 5). Hesitations can be interpreted as defensive elements. The caller's hesitation seems due to the apparent contradiction which exists between the accident being a serious one and only two cars being involved. The caller is addressing the expectation that the operator's question seems to imply, that a serious accident involves several cars.

The question, =how many injured persons, seems to be in line with the caller's implicit focus, i.e. the main issue at hand: Injured people. Notice the latching. The fast pace maintained in the exchange of turns corresponds to the expression of urgency conveyed by the caller through his choice of words: "serious accident". The operator's questions have a precise aim in relation to the organization of the rescue activity (Gilsinan 1989: 340). In fact, =how many injured persons, is necessary in order to decide how many ambulances to dispatch; the second one (line 16), are they trapped?, is to find out if intervention by the fire brigade is necessary. The caller's answer to the first question again indirectly underlines the urgency and the need for prompt intervention, by commenting on the critical condition of one of the injured people (line 13-14), eh that ( ) one is certainly in a critical condition. In the reply to the second question, the caller signals difficulties in providing an answer. It starts with a clearly audible intake of breath, there are various delaying objects and a short pause, connoting a dispreferred-action turn shape (Pomerantz 1984: 64). Then the caller begins an explanation, an account, hh wel- ( ) eh (.) I because I don't know I [( )]. The delay objects are prefaced with a negative answer which needs to be accounted for.

The operator does not let him finish his reply and asks for his telephone number, interrupting the questioning series, [don]'t worry leave me your telephone number. "Don't worry" (line 19) addresses the caller's need to account for his inability to provide relevant details about the accident. ${ }^{4}$ In this case, interrupting the caller in the middle of the sentence is not rude. On the contrary, it seems to be in line with the caller's implicit request for urgent intervention. Asking for the telephone number is very important because it allows the operator to call back, but it is also a way to insert an element of change into the flow of communication and to re-establish cooperativeness with the interlocutor. It appears as a strategy to re-establish emotional contact with the caller.

The next turn is not clearly audible, it is a question aimed at clarifying if the caller is able to see the injured persons, listen do you (see that) the persons are not moving? The caller's answer explains the reason why he is not able to provide more information. The caller is not present at the site of the accident but he is at home, they have told me to call I was here at home (they have) "call 118 immediately" and I did I didn't go down my brother went down he is down. The caller is justifying himself. He is making himself accountable for the fact of not being able to provide the information that the operator is asking him for. As Heritage (2005: 200) has pointed out: "participants in conversation hold one another to strict standards of accountability concerning such matters as who knows what, when and with what degree of epistemic priority relative to others in the interaction."

4 "Don't worry" (non si preoccupi) (line 19) does not address the state of mind of the caller, as suggested by a reviewer. "Non si preoccupi" is a courtesy form in Italian "No grazie, non si preoccupi" (no thanks, don't worry) is a standard reply form for refusing an offer of help in Italian. 
In this case, the caller feels compelled to provide an account of why is not able to provide more information, indicating spatial references. His positioning, I was here at home, I didn't go down, is contrasted with his brother's, my brother went down. In this way the caller manages to account for his lack of knowledge and for not being at the site of the accident, because his brother is there, he is down. In this way the caller shows cooperation with the "institutional need" expressed by the operator, an inquiry which he probably does not fully understand the meaning of nor the necessity for it. His perspective seems to be: "Please come in a hurry. There is somebody who needs help urgently."

At this point the operator stops asking questions and begins to give instructions. The operator informs the caller that she is going to call him back, asking him to leave the line free, okay then leave this numb [er free and I'll call back directly. Notice at the end of the turn, okay? $=$, the operator is negotiating her next call with the caller. The caller does not explicitly answer this last question, but thanks the operator. At line 37-38 the operator formulates the answer to the request for help and she makes the reason for her next call explicit - the need for further information, and you will give me more information while I send them there - and again she repeats, okay? $=$. The operator is again soliciting the caller's cooperation, who this time replies clearly with an affirmation, yes. Then thanks on both parts follow, ending the call. All through this call, formal address is used.

In relation to the caller's expression of urgency and anxiety, giving instructions seems to have a different emotional impact from that of asking questions. Having to reply to questions and provide information is often perceived by callers as delaying assistance and increasing their anxiety. Following instructions, instead, involves callers in the rescue activity, gives them direction and tends to reduce their anxiety. In this call, the operator's instructions appear as an important device to manage the caller's anxiety, ensuring the caller's cooperation and pursuing her institutional objective.

This is an ordinary call, seemingly insignificant at first, but it is also a remarkable piece of conversation in relation to emotional communication: The operator is able to maintain the caller's cooperation taking into account and replying to the subtle emotional signals that are coming from him. It seems that emotional negotiation is taking place throughout the call - the operator's ability to conversationally acknowledge the caller's anxiety and urgency buys his cooperation while the caller keeps answering questions, the need for which he probably does not fully understand. The operator is able to maintain emotional contact with the caller, that is, she is able to show awareness of the emotional content of her interlocutor's turns, responding to the emotional clues produced by the caller. The operator makes an effect to align herself with the caller.

In these calls, communication seems to be simultaneously played out on two levels: 1) explicit: The request for help and the request for the information needed to organise the rescue activities; 2) implicit: The expression of emotional content, the sense of urgency on the part of the caller and the attempts to deal with the caller's anxiety on the part of the operator, in order to obtain the necessary information. In many cases we see the operator reacting to the caller's subtle cues expressing anxiety and haste which are conveyed mainly implicitly though the choice of words, ironic remark, speed of speech delivery, latching and overlapping. 


\section{Conclusion}

This study shows different levels of the ability of operators to obtain caller's collaboration in providing information despite callers' emotional stress, and this is achieved through interactional moves that explicitly or implicitly address the callers' emotional stress and their expression of haste and urgency. Whalen \& Zimmerman (1998) have pointed out the contrast between the exceptionality of the situation, for the caller, and the ordinariness of it for the operator as a key aspect of emergency calls. This study points out the emotional dimension of this contrast. Callers are very often emotionally aroused, whereas operators are generally not. Moreover, the questioning series is often resisted by callers and perceived as a way of delaying assistance which often causes caller anger. Operators, who show an awareness of the emotional state of callers and respond to callers' emotional clues, appear more able to maintain effective communication and eventually obtain the information they need.

Institutionally operators work as a filter, establishing the priority level of the event and the type of resources and personnel to be allocated to the rescue activity. Callers invariably phone with a sense of urgency. Operator questioning is often seen as uncooperative and inappropriate by callers and can lead to angry remarks. This study compares four calls that document this type of dynamic, describing the operator's orientation towards the emotional content of each caller, emotional alignment, or lack of it, emotional misalignment. In particular the following aspects were examined: The speed of speech delivery, the form of address and specific strategies to regain emotional contact, such as: Asking the callers for their telephone number; reassuring callers, informing that the ambulance is on its way; the operator addressing the caller by name etc.

An important aspect in these calls is the alignment among interlocutors in relation to pace, in particular the operator's attention towards the speech delivery rhythm and a fast pace in the alternation between turns, marked by lack of pause, latchings and overlaps. In the first call we have total misalignment between the operator's (slow) and the caller's (fast) pace, with this difference in the speed of speech delivery among interlocutors characterizing the call. The second call is marked by pauses, attributable mostly to the operator, very short ones, but noticeable in this type of environment. In the third call the operator responds rapidly after the caller's ironical comment, in so doing acknowledging the expression of urgency indirectly expressed by the comment. In the last call the operator maintains a fast pace and cuts the caller short; nevertheless, a great sense of cooperation is achieved. Maintaining a fast speed of speech delivery and of alternation of turns appear the most effective form of alignment to callers' expression of haste and sense of anxiety.

The form of address and addressing the caller by name appears to have different effects in different cases. In the last call, in which a great sense of cooperation is achieved among interlocutors, only formal address is used, but also in the first call in which there is a complete breakdown in communication. In the second extract, pag.10, the use of informal address, though, appears as an operator's move towards aligning with the caller; in the third extract too, at page 13, where the operator not only use the informal address, but he also addresses the caller by name. Certainly, it would be useful to examine this aspect further, by analysing other calls. 
Among operators' strategies, asking callers for their telephone number seems to be a very effective strategy to introduce an element of change when the interaction gets agitated and to re-establish cooperation among interlocutors. It is an easy question to be answered. In fact, an aspect that would be very worthwhile to study further is the different emotional impact of asking question versus giving instructions. In the last call, the operator at a certain point stops asking questions and starts giving instructions. The emotional effect appears to be reassurance. In fact it makes sense, since in an emotionally aroused state replying to questions is more difficult than following instructions, because in following instructions, thinking and deciding are delegated to the operator.

The operators' acknowledgment of the caller's emotional cues, their orientation towards the emotional content of the caller's turn makes a substantial difference in relation to the communication outcomes of the interaction. In the last call, the operator maintains a fast pace, keeps the call very short and negotiates a new call, acknowledging the caller's indirect clues expressing urgency and cooperation is achieved. In the first call, the operator slows down the speech delivery rhythm, when confronted with the caller's expression of urgency and she does not attempt in any way to establish emotional contact with the caller. The result is a complete breakdown in communication. Orienting oneself towards the emotional content of the caller's turn, and responding to the caller's emotional cues, appears to be a pertinent and relevant professional skill for operators in emergency rooms.

\section{Acknowledgements}

I would like to thank all the personnel of the 118 call centre in Central Italy for their cooperation during the data collection, in particular the coordinator of the team who helped me to obtain the recordings of the calls; a particular thanks also to an anonymous reviewer for the very useful and inspiring comments.

\section{Transcript notations}

(.) Stop or pause in the rhythm of the conversation

? Rising intonation

! $\quad$ Excited tone

( ) Word(s) spoken, but not audible

(dog) Word(s) whose hearing is doubtful

((laugh) ) Transcriber's description

... Part of the transcript has been omitted

[ Overlapping utterances at this point

$=\quad$ No gaps in the flow of conversation 


\begin{tabular}{ll}
$(0.4)$ & Pause timed in tenth of seconds \\
- & Cutoff \\
$: \ldots::$ & Elongation \\
hh & Audible aspiration \\
URGENT & Increased volume \\
URGENT & Particularly increased volume and high pitch \\
\hline last week $<$ & Quick pace or quicker pace in relation to previous talk of the same \\
$<$ tell me $>$ & speaker \\
$\uparrow \downarrow$ & Slow pace or slower pace in relation to previous talk of same speaker \\
& Rising and falling shifts in intonation
\end{tabular}

\section{References}

Arminen, I., and M. Halonen (2007) Laughing with and at patients: The roles of laughter in confrontations in addiction group therapy. The Qualitative Report 12.3: 484-513.

Bamberg, M. (1997) Language, concepts and emotions: The role of language in the construction of emotions. Language Sciences 19.4: 309-340.

Caffi, C., and.R.W. Janney (1994) Toward a pragmatics of emotive communication. In C. Caffi, and R.W. Janney (eds.), Involvement in language, special issue of Journal of Pragmatics 22.3/4: 325-373.

Denzin, N.K. (1984) On Understanding Emotion. San Francisco: Jossey-Bass.

Drew, P. (1998) Complaints about transgressions and misconducts. Research on Language and Social Interaction 31.3: 295-325.

Edwards, D. (1999) Emotion discourse. Culture \& Psychology 5: 271-91.

Edwards, D. (2001) Emotion. In M. Wetherell, S. Taylor, and S.J. Yates (eds.), Discourse Theory and Practice: A Reader. London: Sage, pp. 236-246.

Edwards, D. (2005) Discursive psychology. In K. Fitch, and R. Sanders (eds.), Handbook of Language and Social Interaction. Mahwah, NJ: Erlbaum, pp. 257-73.

Edwards, D. (2006) Discourse, cognition and social practices: The rich surface of language and social interaction. Discourse Studies 8.1: 41-49.

Edwards, D. (2007) Introduction. Research on Language and Social Interaction 40.1: 1-7.

Fineman, S. (2000) (ed.) Emotion in Organizations. Second Edition. London: Sage.

Firth, H., and C. Kitzinger (1998) 'Emotion work' as a participant resource: A feminist analysis of young women's talk-in-interaction. Sociology 32.2: 299-320.

Forsberg, H. (1999) Speaking of emotions in child protection practices. In A. Jokinen, K. Juhila, and T. Pösö (eds.), Constructing Social Work Practices. Aldershot: Ashgate, pp. 116-132. 
Freese J., and D.W. Maynard (1998) Prosodic features of bad news and good news in conversation. Language in Society 27.2: 195-219.

Garfinkel, H. (1967) Studies in ethnomethodology. Englewood Cliffs, N.J.: Prentice-Hall.

Gilsinan, J.F. (1989) They is clowning tough: 911 and the social construction of reality. Criminology 27: 329344.

Goffman, E. (1967) Interaction Ritual. Garden City, NY: Anchor.

Goodwin, M.H., and C. Goodwin (2000) Emotion within situated activity. In A. Duranti (ed.), Linguistic anthropology: A reader. Maldem, MA, Oxford: Blackwell, pp. 239-257.

Harré, R. (1988) (ed.) The Social Construction of Emotions. Oxford: Basil Blackwell.

Harré, R. (2009) Emotions as cognitive-affective-somatic hybrids. Emotion Review 1.4: 294-301.

Heath, C. (1989) Pain talk: The expression of suffering in the medical consultation. Social Psychology Quarterly 52: 113-25.

Hepburn, A. (2004) Crying: Notes on description, transcription and interaction. Research on Language and Social Interaction 37.3: 251-290.

Hepburn, A., and J. Potter (2007) Crying receipts: Time, empathy and institutional practice. Research on Language and Social Interaction 40.1: 89-116.

Heritage, J. (2005) Cognition in discourse. In Molder, and J. Potter (eds.), Conversation and Cognition. Cambridge: Cambridge University Press, pp. 184-202.

Heritage, J., and A. Lindström (1998) Motherhood, medicine and morality: Scenes from a medical encounter. Research on Language and Social Interaction 31: 397-438.

Hochschild, A.R. (1979) Emotion work, feeling rules, and social structure. American Journal of Sociology 85.3: 551-575.

Imbens-Bailey, A., and A. McCabe (2000) The discourse of distress: A narrative analysis of emergency calls to 911. Language and Communication 20.3: 275-296.

Jayyusi, L. (1984) Categorization and the moral order. London: Routledge \& Kegan Paul.

Jayyusi, L. (1991) Values and moral judgement: Communicative praxis as moral order. In G. Button (ed.), Ethnomethodology and the human sciences. Cambridge: Cambridge University Press, pp. 227-51.

Jefferson, G. (1984) On the organization of laughter in talk about troubles. In J.M. Atkinson, and J. Heritage (eds.), Structures of Social Action: Studies in Conversation Analysis. Cambridge: Cambridge University Press, pp. 346-69.

Jefferson, G. (1985) An exercise in the transcription and analysis of laughter. In T.A. van Dijk (ed.), Handbook of discourse analysis. London: Academic Press. Vol. 3, pp. 25-34.

Jefferson, G., H. Sacks, and E.A. Schegloff (1987) Notes on laughter in the pursuit of intimacy. In G. Button, and J.R.E. Lee (eds.), Talk and social organisation. Clevedon: Multilingual Matters, pp. 152-205. 
Kidwell, M. (2006) "Calm Down!": The role of gaze in the interactional management of hysteria by the police. Discourse Studies 8.6: 745-770.

Maynard, D.W. (1998) Praising versus blaming the messenger: Moral issues in deliveries of good and bad news. Research on Language and Social Interaction 31.3: 359-395.

Mehan, H.(1979) 'What time is it, Denise?': Asking known information questions in classroom discourse. Theory into Practice 28.4: 285-294.

Monzoni (2008) Introducing direct complaints through questions: The interactional achievement of presequences. Discourse Studies 10.1: 73-87.

Monzoni, C.M. (2009a) Direct complaints in (Italian) calls to the ambulance: The use of negatively framed questions. Journal of Pragmatics 41: 2465-2478.

Monzoni, C.M.(2009b) Preference organization and complaining in (Italian) 118 emergency calls to the ambulance. In E. Weigand (ed.), Dialogue Analysis IX.1: 249-261.

http://usheffield.academia.edu/ChiaraMonzoni/Papers/1090636/Preference_Organization_and_Complaining_i n_Italian_118_Emergency_Calls_to_the_Ambulance

Nikander, P. (2007) Interprofessional decision making in elderly care: Morality, criteria, and help allocation. In Isabella Paoletti (ed.), Family Caregiving. Relational and Institutional Issues. New York: Nova Science, pp. 319-332.

Paoletti, I. (2012) The issue of conversationally constituted context and localization problems in emergency calls. Text \& Talk 32.2: 191-210.

Paoletti, I. (2012) Eliciting a response from an audience. Paper presented at the SLE 2012, 45th Annual Meeting of the Societas Linguistica Europaea 29 Aug -1 Sept. Stockholm, Sweden.

Paoletti, I. (2009) Communication and diagnostic work in medical emergency calls in Italy. Computer Supported Cooperative Work 18.2-3: 229-250.

Paoletti, I. (2006) Gender and communication in the control rooms of medical emergency number in Italy. In M. Barrett, and M.J. Davidson (eds.), Gender and Communication issues at work. Aldershot: Ashgate, pp.166-179.

Pepin N. (2008) Studies on emotions in social interactions Bulletin Suisse de Linguistique Appliquée 88: 1-18.

Pomerantz, A. (1984) Agreeing and disagreeing with assessments: Some features of preferred/dispreferred turn shapes. In J.M. Atkinson, and J. Heritage (eds.), Structures of Social Action: Studies in Conversation Analysis. Cambridge: Cambridge University Press, pp. 57-101.

Potter, J. (2005) Making psychology relevant. Discourse and Society 16: 739-747.

Potter, J., and D. Edwards (2003) Sociolinguistics, cognitivism and discursive psychology. International Journal of English Studies 3.1: 93-109.

Reisenzein, R., and S.A. Döring (2009) Ten perspectives on emotional experience: Introduction to the special issue. Emotion Review 1.3: 195-205.

Ruusuvuori, J. (2007) Managing affect: Integration of empathy and problem-solving in health care encounters. In Discourse Studies 9: 597-622. 
Sacks, H. (1992) Lectures on conversation, vol I \& II. Oxford: Blackwell.

Schegloff, E.A. (1998) Reflections on studying prosody in talk-in-interaction. Language and speech 41: 235 63 .

Schegloff, E.A., Gail Jefferson, and Harvey Sacks (1977) The preference for self correction in the organization of repair in conversation. Language 53.2: 361-382.

Selting M. (1992) Intonation as a contextualization device: Case studies on the role of prosody, especially intonation, in contextualizing story telling in conversation. In P. Auer, and A. di Luzio (eds.), The contextualization of language. Amsterdam: John Benjamins Publishing Company, pp. 233-258.

Seltin, M (1994) Emphatic speech style: With special focus on the prosodic signalling of heightened emotive involvement in conversation. Journal of Pragmatics 22.3-4: 375-408.

Suchman, A.L., K. Markakis, H.B. Beckman, and R. Frankel (1997) A model of empathic communication in the medical interview. Journal of the American Medical Association 277.8: 678-682.

Toerien M., and C. Kitzinger (2007) Emotional labour in action: Navigating multiple involvements in the beauty salon. Sociology 41: 645-662.

Tracy, S.J., and K. Tracy (1998a) Emotion labor at 911: A case study and theoretical critique. Research of Applied Communication Research 26.4: 390-411.

Tracy, K., and S.J. Tracy (1998b) Rudeness at 911: Reconceptualizing face and face attack. Human Communication Research 25.2: 225-251.

Tracy, K. (1997) Interactional trouble in emergency services requests: A problem of frames. Research on Language and Social Interaction 30.4: 315-343.

Turner, J.H. (2009) The sociology of Emotion: Basic theoretical arguments. Emotion Review 1.4: 340-354.

Voutilainen, L., A. Perakyla, and J. Ruusuvuori (2010) Recognition and interpretation: Responding to emotional experience in psychotherapy. Research on Language and Social Interaction 43.1: 85-107.

Wakin, M.A., and D.H. Zimmerman (1999) Reduction and specialization in emergency and directory assistance calls. Research on Language and Social Interaction 32.4: 409-437.

Wetherell, M., S. Taylor, and S.J. Yates (eds.) (2001) Discourse Theory and Practice: A Reader. London: Sage Publications.

Whalen, Jack, and Don H. Zimmerman (1998) Observation on the display and management of emotions in natural occurring activities: The case of "hysteria" in calls to 9-1-1. Social Psychology Quarterly 61.2: 141159.

Whalen, J., D.H. Zimmerman, and M.R. Whalen (1988) When words fail: A single case analysis. Social Problems 35.4: 335-362.

Whalen, M.R., and D.H. Zimmerman (1987) Sequential and institutional contexts in calls for help. Social Psychology Quarterly 50.2: 172-185. 
White, G.M. (1990) Moral discourse and the rhetoric of emotions. In C.A. Lutx, and L. Abu-Lughod (eds.), Language and the Politics of Emotion. Cambridge: Cambridge University Press, and Editions de la Maison des Sciences de l'Homme, pp. 46-68.

Wierzbicka, A. (2009) Language and metalanguage: Key issues in emotion research. Emotion Review 1.1: 314.

Wilce, J.M. (2009) Language and Emotion. Cambridge, UK: Cambridge University Press.

Wilkinson S., and C. Kitzinger (2006) Surprise as an interactional achievement: Reaction tokens in conversation. Social Psychology Quarterly 69.2: 150-182.

Zimmerman, D.H. (1992a) The interactional organization of calls for emergency assistance. In P. Drew, and J. Heritage (eds.), Talk at work. Cambridge: Cambridge University Press, pp. 418-469.

Zimmerman, D.H. (1992b) Achieving context. Openings in emergency calls. In G. Watson, and R.M. Seiler (eds.), Text in context. Newbury Park: Sage, pp. 35-51.

ISABELLA PAOLETTI is a researcher at CLUNL, the Linguistic Centre of the Universidade Nova of Lisbon. Her research interests are informed by ethnomethodology, conversation analysis and associated ethnographic approaches, studying interaction in institutional settings. Among her recent publications: 'The issue of conversationally constituted context and localization problems in emergency calls' in Text and Talk (32.2: 191-210) and 'Sociolinguistics' in Sociopedia.ISA, (London: Sage).

Address: CLUNL, Universidade Nova de Lisboa, Avenida de Berna 26C, 1069-61 Lisbon, Portugal. Tel.: +351-217-938928; e-mail: isabella.paoletti@fcsh.unl.pt 